\title{
THE EFFECT OF ADDITION OF CANTHAXANTHIN IN FEED TO INCREASE THE VISUAL VIEW OF COMET FISH, Carassius auratus (Linnaeus, 1758)
}

\author{
Eka Sary Septiyani*1, Indra Gumay Yudha', Yeni Elisdiana ${ }^{1}$
}

\begin{abstract}
One effort made to improve the color quality of comet fish is to add canthaxanthin. Canthaxanthin is a red-orange pigment found in plants, fungi, bacteria, crustaceans, sea trout, and algae. This study aims to determine the optimum dose of canthaxanthin given in feed to improve comet fish' color quality. This research is also expected to be beneficial for fish farmers related to the use of canthaxanthin to improve comet fish' color quality. This study used 5 treatments with 3 replications. This research was conducted in April-June 2019 at the Aquaculture Laboratory, Department of Fisheries and Marines, University of Lampung. The parameters observed were color measurement using the Red Blue Green (RGB) method, converted into the Hue Saturation Brightness (HSB) value, color measurement by the scoring method, and water quality. The addition of canthaxanthin in diets with different doses showed the highest results in treatment $C(P<0.05)$ on comet fish visual appearance. The results showed that the best dose in this study was the addition of canthaxanthin as much as $125 \mathrm{mg} / \mathrm{kg}$ of feed.
\end{abstract}

Keywords: canthaxanthin, color, comet fish, feed

\section{Pendahuluan}

Menurut Lapadi et al. (2017) ikan komet memiliki keunggulan warna yang bermacam-macam, seperti putih, kuning, merah, ataupun perpaduan dari warna-warna tersebut. Warna merupakan salah satu parameter dalam penentuan kualitas ikan hias (Fitrianai et al., 2013). Salah satu upaya untuk meningkatkan kualitas warna pada ikan adalah dengan menambahkan sumber pigmen ke dalam pakan.

Beberapa jenis karotenoid yang digunakan untuk meningkatkan kualitas warna pada hewan akuatik adalah astaxantin, canthaxantin, lutein, zeaxantin, dan tunaxantin. Astaxanthin dan canthaxanthin merupakan pigmen karotenoid yang banyak tersedia di alam, seperti pada fitoplankton dan krustasea. Astaxanthin dan canthaxanthin merupakan pigmen karatenoid yang memiliki warna merah. Sumber dapat berasal dari berbagai organisme laut, seperti tumbuhan mikroskopik (mikroalga), beberapa jenis ikan (salmon, tuna, dan trout), serta krustasea (Yesilayer et al., 2011). Menurut Pasarin et al. (2018) canthaxanthin adalah oxycarotenoid oranye-merah yang ditemukan di

\footnotetext{
* E-mail: ekunngg19@gmail.com

${ }^{1}$ Jurusan Perikanan dan Kelautan, Fakultas Pertanian, Universitas Lampung

Jl. Prof. S. Brodjonegoro No.1 Gedong Meneng Bandar Lampung, 35145
} 
krustasea, jamur dan ganggang, khususnya digunakan dalam pemberian warna. Canthaxanthin memiliki aktivitas antioksidan dan meningkatkan komunikasi fungsional antara sel secara langsung atau melalui pembentukan 4-asam oksoretinoat, yang juga bisa merangsang reseptor asam retinoat. Oleh karena itu, perlu dilakukan penelitian untuk menentukan dosis canthaxanthin yang tepat yang ditambahkan ke dalam pakan sehingga dapat meningkatkan kualitas warna ikan komet.

Tujuan dari penelitian ini adalah untuk mempelajari pengaruh penambahan canthaxanthin pada pakan terhadap tampilan visual dan kualitas warna digital (Hue Saturation Brightness) serta menentukan dosis canthaxanthin yang optimum diberikan dalam pakan untuk meningkatkan kualitas warna ikan komet (Carassius auratus).

\section{Metode}

Komet sebagai ikan uji berasal dari Balai Besar Budidaya Perikanan Air Tawar (BBBPAT) Sukabumi, Jawa Barat yang berukuran 2-3 cm dipelihara dalam akuarium 40x30×30 $\mathrm{cm}^{3}$ dengan padat tebar 10 ekor/akuarium. Pakan yang diberikan selama penelitian adalah pakan buatan yang ditambahkan canthaxanthin dan astaxanthin berbeda dengan 5 perlakuan dan 3 ulangan. Perlakuan $\mathrm{K}^{-}$adalah tanpa penambahan canthaxanthin dan astaxanthin, perlakuan $\mathrm{K}^{+}$adalah dengan penambahan astaxanthin 75 $\mathrm{mg} / \mathrm{kg}$ pakan komersil, perlakuan A adalah penambahan canthaxanthin 75 $\mathrm{mg} / \mathrm{kg}$ pakan komersil, perlakuan B adalah penambahan canthaxanthin $100 \mathrm{mg} / \mathrm{kg}$ pakan komersil, perlakuan $\mathrm{C}$ adalah penambahan canthaxanthin 125 mg/kg pakan komersil.

Pengukuran analisis warna dengan metode RGB (Red Green Blue)

Setiap objek penelitian difoto dalam akuarium berukuran $10 \times 10 \times 15$ $\mathrm{cm}^{3}$ menggunakan kamera Canon EOS 550D 18 MP yang dilengkapi dengan lensa kit Canon 18-55 mm. Pencahayaan bersumber dari lampu neon 40 watt yang diletakkan di bagian depan atas akuarium. Pengambilan foto dilakukan pada jarak $\pm 10 \mathrm{~cm}$ di depan akuarium. Foto yang dihasilkan disimpan dalam format JPG. Gambar yang diperoleh dianalisis menggunakan software imageJ 1.440 dengan tambahan flugin color inspector 3D untuk menampilkan grafis tiga dimensi warna. Selanjutnya ditentukan persentase setiap nilai $\mathrm{R}, \mathrm{G}, \mathrm{B}$ dihitung menggunakan rumus:

$\% \mathrm{R}=$ (rata-rata $\mathrm{R} /($ rata-rata $\mathrm{R}+$ ratarata $\mathrm{G}+$ rata-rata $\mathrm{B})$ ) x $100 \%$

$\% \mathrm{G}=$ (rata-rata $\mathrm{G} /$ (rata-rata $\mathrm{R}+$ ratarata $\mathrm{G}+$ rata-rata $\mathrm{B})$ ) x $100 \%$

$\% \mathrm{~B}=$ (rata-rata $\mathrm{B} /$ (rata-rata $\mathrm{R}+$ ratarata $\mathrm{G}+$ rata-rata $\mathrm{B})) \times 100 \%$

Nilai rata-rata RGB dikonversi pada model warna HSB (Hue Saturation Brightness / jenis warna, kejenuhan, kecerahan) menggunakan aplikasi RGB to HSB Calculator. Bagian ikan yang dianalisis adalah badan ikan yang berwarna.

Analisis warna dengan menggunakan metode scoring

Setiap ikan difoto dengan menggunakan kamera Canon EOS 
550D yang dilengkapi lensa kit Canon 18-55 mm kemudian gambar ikan yang dihasilkan diberi nilai dengan menggunakan skala warna dari yang terendah sampai tertinggi. Skala warna yang digunakan adalah Modified Tocca Color Finder (Gambar 1).

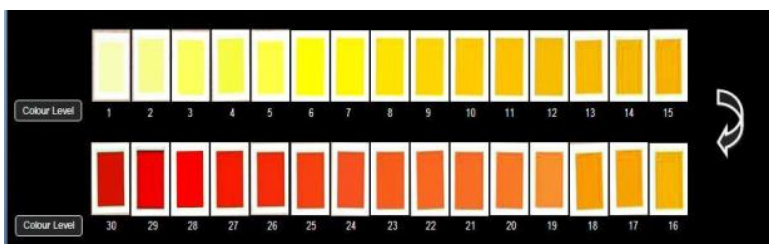

Gambar 1. Skala warna yang digunakan dalam penelitian

\section{Hasil dan Pembahasan}

Pengamatan analisis warna dengan menggunakan metode RGB (Red Green Blue)

Setiap perlakuan yang diberikan dikarakterisasi dalam bentuk rata-rata (mean) dan persentase nilai digital RGB (Red Green Blue). Perlakuan $\mathrm{K}^{-}$tanpa penambahan canthaxanthin dan astaxanthin memiliki komponen warna digital merah (R) sebesar 43\%, hijau (G) sebesar 38\% dan biru (B) sebesar $19 \%$. Perlakuan $\mathrm{K}^{+}$dengan menggunakan penambahan astaxanthin sebanyak $75 \mathrm{mg} / \mathrm{kg}$ memiliki komponen warna digital merah (R) sebesar 46\%, hijau (G) sebesar $40 \%$ dan biru (B) sebesar 14\%. Perlakuan A dengan penambahan canthaxanthin $75 \mathrm{mg} / \mathrm{kg}$ memiliki komponen warna digital merah (R) sebesar 47\%, hijau (G) sebesar 40\% dan biru (B) sebesar 13 $\%$. Perlakuan B dengan penambahan canthaxanthin $100 \mathrm{mg} / \mathrm{kg}$ memiliki komponen warna digital merah (R) sebesar 50\%, hijau (G) sebesar $40 \%$ dan biru (B) sebesar 10\%. Perlakuan $\mathrm{C}$ dengan penambahan canthaxanthin $125 \mathrm{mg} / \mathrm{kg}$ memiliki komponen warna digital merah (R) sebesar 51\%, hijau (G) sebesar 37\% dan biru (B) sebesar $12 \%$. Secara lengkap, karakter warna RGB setiap perlakuan disajikan pada Tabel 1.

Tabel 1. Nilai digital warna pada ikan komet berdasarkan model RGB (Red Green Blue)

\begin{tabular}{|c|c|c|c|c|c|}
\hline Perlakuan & $\mathbf{N}$ & Keterangan & $\mathbf{R}$ & $\mathbf{G}$ & B \\
\hline \multirow{2}{*}{$\mathrm{K}^{-}$} & 3 & Mean \pm SD & $164,5 \pm 6,06$ & $143,5 \pm 18,99$ & $73 \pm 25,51$ \\
\hline & 3 & $\%$ Mean & 43 & 38 & 19 \\
\hline \multirow{2}{*}{$\mathrm{K}^{+}$} & 3 & Mean \pm SD & $191,21 \pm 57,05$ & $166,45 \pm 50,81$ & $57,05 \pm 29,39$ \\
\hline & 3 & $\%$ Mean & 46 & 40 & 14 \\
\hline \multirow{2}{*}{ A } & 3 & Mean \pm SD & $181,57 \pm 13,03$ & $151,33 \pm 8,13$ & $49,90 \pm 28,90$ \\
\hline & 3 & $\%$ Mean & 47 & 40 & 13 \\
\hline \multirow{2}{*}{ B } & 3 & Mean \pm SD & $194,67 \pm 23,18$ & $158,67 \pm 32,32$ & $39,5 \pm 13,76$ \\
\hline & 3 & $\%$ Mean & 50 & 40 & 10 \\
\hline \multirow{2}{*}{$\mathrm{C}$} & 3 & Mean \pm SD & $132,17 \pm 14,22$ & $95,5 \pm 11,46$ & $31,33 \pm 18,93$ \\
\hline & 3 & $\%$ Mean & 51 & 37 & 12 \\
\hline
\end{tabular}




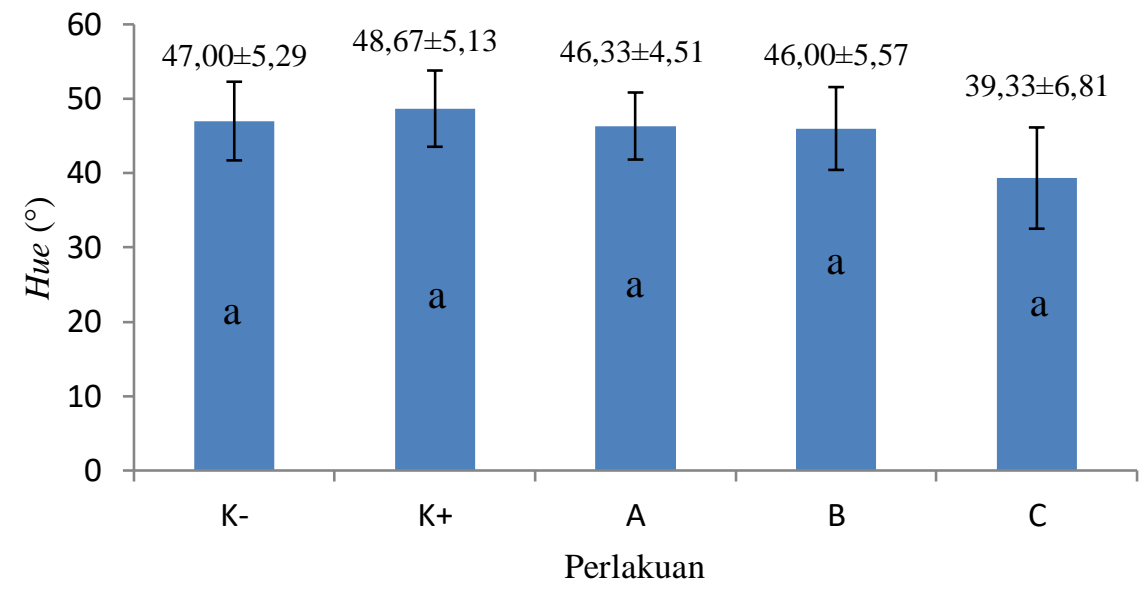

Keterangan: Huruf superscript yang sama menunjukkan nilai yang tidak berbeda nyata $(\mathrm{P}>0,05)$ Gambar 2. Nilai rata-rata hue $(\mathrm{H})$ ikan komet

HARI KE-20

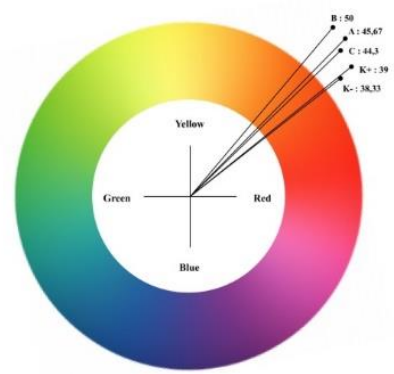

HARI KE-40

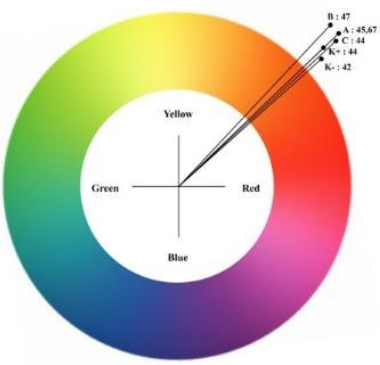

HARI KE-60

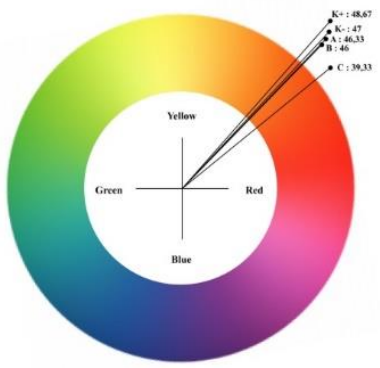

Gambar 3. Nilai hue ikan komet selama penelitian

Berdasarkan hasil penelitian, nilai hue pada ikan komet berkisar pada angka $34-52^{\circ}$. Nilai rata-rata hue (H) terendah yaitu pada perlakuan $\mathrm{C}$ sebesar 39,33 $\pm 6,81$. Hasil uji statistik nilai hue $(\mathrm{H})$ menunjukkan hasil yang tidak signifikan $(\mathrm{P}>0,05)$. Menurut Guillaume et al. (2001), parameter $\mathrm{H}$ didefinisikan sebagai jenis warna dengan kisaran hue dari $0-90^{\circ}$ yang menunjukkan jenis warna merah, jingga, dan kuning. Nilai hue merupakan tingkatan warna dari spektrum cahaya yang ditangkap oleh mata dan merupakan refleksi dari struktur dan warna karotenoid. Nilai hue menunjukkan perubahan warna dari merah, kuning, biru, hijau, dan ungu, hingga merah kembali dalam system warna. 


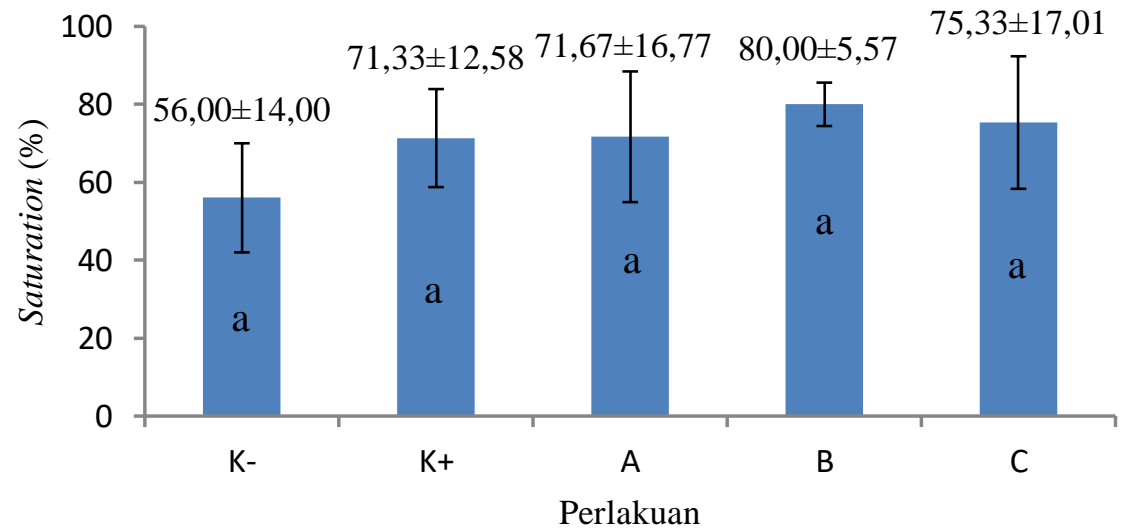

Keterangan: Huruf superscript yang sama menunjukkan nilai yang tidak berbeda nyata $(\mathrm{P}>0,05)$ Gambar 4. Nilai rata-rata saturation (S) ikan komet

Berdasarkan nilai rata-rata perlakuan $\mathrm{K}^{+}$sebesar $71,33 \pm 12,58 \%$, saturation (S), perlakuan $\mathrm{B}$ dan nilai saturation terendah pada menunjukkan nilai yang lebih tinggi perlakuan $\mathrm{K}^{-}$sebesar $56,00 \pm 14,00 \%$. yaitu sebesar $80,00 \pm 5,57 \%$, selanjutnya diikuti perlakuan $\mathrm{C}$ sebesar 75,33 $\pm 17,01 \%$, kemudian perlakuan A sebesar 71,67 $\pm 16,77 \%$, Setelah dilakukan uji anova untuk nilai saturation didapatkan hasil yang tidak berpengaruh $(\mathrm{P}>0,05)$ antar perlakuan.

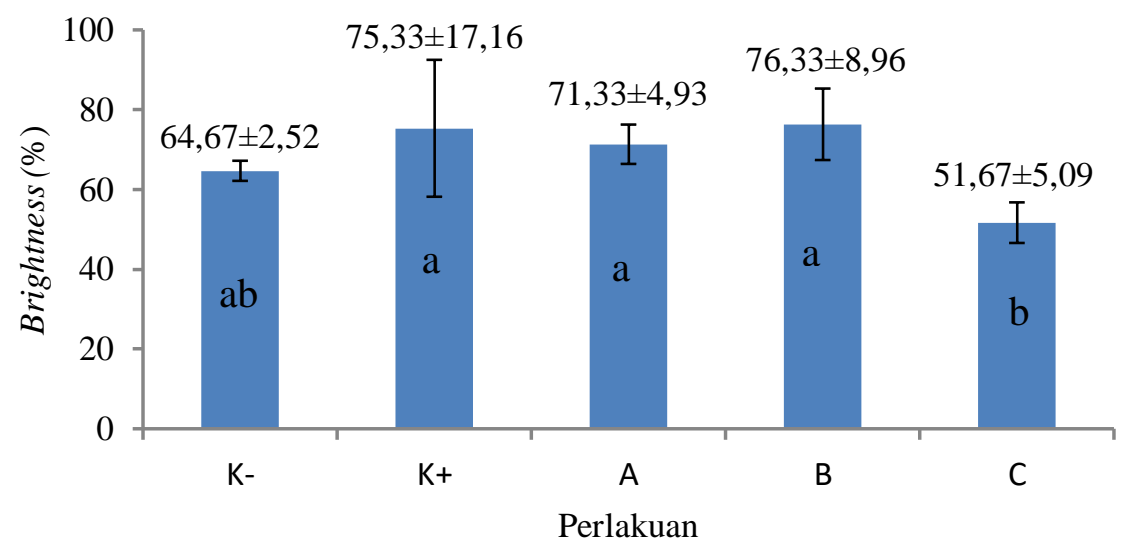

Keterangan: Huruf superscript yang sama menunjukkan nilai yang tidak berbeda nyata $(\mathrm{P}>0,05)$ Gambar 5. Nilai rata-rata brightness (B) ikan komet

Berdasarkan nilai rata-rata brightness (B), selisih warna terbesar yaitu pada perlakuan B yaitu 76,33\%, perlakuan $\mathrm{K}^{+}$sebesar $75,33 \%$, perlakuan A sebesar 71,33\%, perlakuan $\mathrm{K}^{-}$sebesar $64,67 \%$ dan perlakuan $\mathrm{C}$ sebesar51,67\%. Hasil uji statistik nilai brightness (B) menunjukkan hasil yang signifikan $(\mathrm{P}<0,05)$.

Nilai saturation selama penelitian berkisar antara 46-91\% sedangkan nilai brightness pada ikan komet berkisar antara 47-91\%. Menurut Kusumah et al. (2015) menyatakan bahwa tingkat kecerahan 
dan kejenuhan warna oranye masingmasing ditentukan oleh nilai digital brightness dan saturation. Semakin tinggi nilai brightness dan saturation yang dimiliki, maka warna oranye yang muncul semakin meningkat. Secara visual, warna oranye yang ditampilkan ikan komet selama penelitian memiliki kisaran yang sempit dan spesifik terhadap jenis warna (hue) tersebut.

\section{Pengamatan warna dengan menggunakan metode scoring}

Berdasarkan hasil pengamatan dengan menggunakan metode skoring menunjukkan adanya peningkatan kualitas warna ikan komet selama penelitian. Pada pengamatan pertama penelitian ikan yang digunakan memiliki warna yang seragam namun belum menghasilkan warna yang maksimal, pada pengamatan kedua ikan yang dipelihara menunjukkan perubahan warna di beberapa bagian, pada pengamatan ketiga ikan yang dipelihara menunjukkan perubahan warna yang meningkat, pada pengamatan keempat ikan yang dipelihara menunjukkan perubahan warna yang signifikan dan warna tersebar di beberapa bagian tubuh ikan komet. Setiap 20 hari ikan komet mengalami peningkatan selama penelitian hal tersebut dapat dilihat pada Tabel 2.

Tabel 2. Nilai rata-rata dan tampilan warna ikan komet berdasarkan penilaian scoring

\begin{tabular}{cccc}
\hline \multirow{2}{*}{ Perlakuan } & \multicolumn{3}{c}{ Hari ke } \\
\cline { 2 - 4 } & $\mathbf{2 0}$ & $\mathbf{4 0}$ & $\mathbf{6 0}$ \\
\hline $\mathrm{K}^{-}$ & $0,33 \pm 0,58^{\mathrm{d}}$ & $5,67 \pm 1,53^{\mathrm{d}}$ & $8,00 \pm 1,00^{\mathrm{cde}}$ \\
& $1, \overline{67 \pm 0,58^{\mathrm{c}}}$ & $7,33 \pm 0,58^{\mathrm{cd}}$ & $8,00 \pm 1,00^{\mathrm{cd}}$ \\
$\mathrm{K}^{+}$ & $4,67 \pm 1,53^{\mathrm{b}}$ & $9,33 \pm 2,08^{\mathrm{bc}}$ & $9,33 \pm 1,53^{\mathrm{c}}$ \\
$\mathrm{A}$ & $5,67 \pm 0,28^{\mathrm{b}}$ & $11,33 \pm 2,08^{\mathrm{ab}}$ & $12,33 \pm 1,53^{\mathrm{b}}$ \\
B & $7,33 \pm 0,58^{\mathrm{a}}$ & $12,00 \pm 1,00^{\mathrm{a}}$ & $17,00 \pm 2,65^{\mathrm{a}}$ \\
C & & &
\end{tabular}

Keterangan: Huruf superscript yang sama pada kolom yang sama menunjukkan nilai yang tidak berbeda nyata $(\mathrm{P}>0,05)$

Berdasarkan hasil pengamatan dengan menggunakan metode scoring menunjukkan adanya peningkatan kualitas warna ikan komet selama penelitian. Pada pengamatan pertama penelitian ikan yang digunakan memiliki warna yang seragam namun belum menghasilkan warna yang maksimal, pada pengamatan kedua ikan yang dipelihara menunjukkan perubahan warna di beberapa bagian, pada pengamatan ketiga ikan yang dipelihara menunjukkan perubahan warna yang meningkat, pada pengamatan keempat ikan yang dipelihara menunjukkan perubahan warna yang signifikan dan warna 
tersebar di beberapa bagian tubuh ikan komet.

Hal tersebut dapat terjadi dikarenakan secara fisiologis ikan akan mengubah pigmen yang didapat dari makanannya menghasilkan variasi warna. Fisiologis perubahan warna adalah perubahan warna yang disebabkan oleh gerakan aktivitas pigmen atau kromatofor. Penyerapan ikan ke sumber pigmen dipengaruhi oleh jumlah atau dosis pigmen, struktur kimia jenis tertentu sel pigmen dan kromatofor yang terkandung dalam ikan (Evans et al., 2014).

\section{Kualitas Air}

Kualitas air selama penelitian dapat dilihat pada tabel di bawah ini.

Tabel 3. Parameter kualitas air

\begin{tabular}{ccccccc}
\hline \multirow{2}{*}{$\begin{array}{c}\text { Parameter } \\
\text { kualitas air }\end{array}$} & \multirow{2}{*}{ Standar } & \multicolumn{5}{c}{ Perlakuan } \\
\cline { 3 - 7 } & & $\mathbf{K}^{-}$ & $\mathbf{K}^{+}$ & $\mathbf{A}$ & $\mathbf{B}$ & $\mathbf{C}$ \\
\hline Suhu $\left({ }^{\circ} \mathrm{C}\right)$ & $23-29 *$ & $26-29$ & $25-29$ & $25-29$ & $26-29$ & $25-29$ \\
$\mathrm{pH}$ & $6-8,3^{*}$ & $6,91-7,64$ & $7,00-7,65$ & $6,97-7,64$ & $6,94-7,61$ & $7,01-7,63$ \\
$\mathrm{DO}(\mathrm{mg} / \mathrm{L})$ & $>3^{* *}$ & $3,2-4,9$ & $3,6-4,9$ & $3,3-4,7$ & $3,1-5,0$ & $3,7-5,0$ \\
\hline
\end{tabular}

Keterangan: * Premalatha \& Lipton, 2007

** Sholichin et al., 2012

Menurut Lin et al. (2009) selain faktor genetik dan hormonal, kualitas warna pada ikan dipengaruhi oleh banyak faktor lainnya mulai dari kualitas air. Pengamatan kualitas air yang dilakukan dalam penelitian ini yaitu pengukuran suhu, $\mathrm{pH}$ (derajat keasaman), dan DO (oksigen terlarut). Hasil analisis kualitas air selama penelitian masih dalam batas kelayakan untuk pemeliharaan ikan uji. Adapun kisaran kualitas air pada saat penelitian yaitu suhu berkisar antara $25-29^{\circ} \mathrm{C}, \mathrm{pH}$ berkisar antara 6,91-7,65, dan DO berkisar antara 3,2-5,0 mg/L (Tabel 3). Menurut Premalatha \& Lipton (2007) menyatakan bahwa suhu yang optimal untuk ikan komet berkisar antara $23-29^{\circ} \mathrm{C}$ dan $\mathrm{pH}$ yang optimal yaitu berkisar 6-8,3. Menurut Sholichin et al. (2012) nilai oksigen terlarut yang baik untuk kehidupan dan pertumbuhan ikan adalah >3 $\mathrm{mg} / \mathrm{L}$.

\section{Kesimpulan dan Saran}

Penambahan canthaxanthin dalam pakan dengan dosis berbeda memberikan pengaruh yang berbeda nyata terhadap tampilan visual dan kecerahan (brightness), namun tidak memberikan pengaruh yang berbeda nyata terhadap jenis warna (hue) dan kepekatan (saturation) ikan komet.

\section{Daftar Pustaka}

Evans, D.H., Claiborne, J.B. \& Currie, S. 2014. The Physiology of Fishes, 4 th ed. CRC Press, Boca Raton. $443 \mathrm{hlm}$.

Fitriani, , N., Subamia, I.W., \& Wahyudi, S. 2013. Pertumbuhan dan performansi warna ikan mas koki (Carassius sp.) melalui pengayaan pakan dengan kepala udang. $A l$ Kauniyah: Jurnal Biologi, 6(1): 1-12. 
Guillaume, J.S., Kaushik, P.B., Métailler, R. 2001. Nutrition and Feeding of Fish and Crustacean. Praxis Publishing Ltd, Chichester. 408 hlm.

Kusumah, R.V., Cinderalas, S., \& Prasetio, A.B. 2015. Keragaan warna ikan clown biak (Amphiprion percula) populasi alam dan budidaya berdasarkan analisis gambar digital. Jurnal Riset Akuakultur, 10(3): 345355.

Lapadi, I., Wouw, F., \& Widiastuti, N. 2017. Efisiensi biaya pakan melalui pemanfaatan rayap pohon (Coptotermes sp.) dalam pembesaran ikan mas komet (Carassius auratus auratus). Jurnal Sumberdaya Akuatik Indopasifik, 1(1):1-6.

Lin, Q., Lin, J., \& Huang, L. 2009. Effects of substrate color, light intensity and temperature on survival and skin color change of juvenile seahorses, Hippocampus erectus Perry, 1810. Aquaculture, 298: 157161.

Pasarin, D. \& Rovinaru, C. 2018. Sources of carotenoids and their uses as animal feed additives-a review. Scientific Papers: Series D, Animal Science-The International Session of Scientific Communications of the Faculty of Animal Science, 61(2).

Premalatha, Y., \& Lipton, A. P. 2007. Water quality management in gold fish (Carassius auratus) rearing tanks using different filter materials. Indian Hydrobiology, 10(2): 301-306.

Sholichin. I., Haetami, K., \& Suherman, H. 2012. Pengaruh penambahan tepung rebon pada pakan buatan terhadap nilai chroma ikan mas koki (Carrasius auratus). Jurnal Perikanan dan Kelautan, 3(4): 185-190.

Yeşilayer, N., Aral, O., Karsli, Z., Öz, M., Karaçuha, A., \& Yağci, F. 2011. The effects of different carotenoid sources on skin pigmentation of Goldfish (Carassius auratus). The Issraeli Journal of Aquaculture, IIC: 63: 1-9. 